\title{
Chapter 11. Diagnosis of pediatric CKD
}

- In children, genetic/congenital kidney diseases are more frequent in addition to primary as well as secondary ones. It is therefore important to take the family history as well as past history without omission.

- Because of the frequent occurrence of postural proteinuria, morning first urine should be tested in pediatric urinalysis.

- The Japanese eGFR formula cannot be applied for the evaluation of kidney function in children.

\section{Notable points in pediatric CKD}

- As described above, the prevalence of genetic/congenital kidney disease is high in pediatric CKD. Diagnostic imaging by ultrasonography is of importance, especially because most kidney diseases are secondary to urinary tract abnormalities.

- The serum creatinine $(\mathrm{Cr})$ is most noteworthy in the evaluation of pediatric $\mathrm{CKD}$. The normal range varies among children of different ages so that a younger child who has a smaller amount of muscle has a lower $\mathrm{Cr}$ level. Therefore, it is important not to underestimate the clinical state. A difference of $0.1 \mathrm{mg} / \mathrm{dl}$ of serum $\mathrm{Cr}$ may be significant. An estimation formula of kidney function applicable to children is now under development by the Japanese Society of Pediatric Nephrology. For the time being, using the estimating measures shown below or Schwartz's equation is recommended.

- Rough standard values of serum creatinine in the child: $0.2 \mathrm{mg} / \mathrm{dl}$ or so for a 1-year-old child; $0.3 \mathrm{mg} / \mathrm{dl}$ for a 4-year-old child; $0.4 \mathrm{mg} / \mathrm{dl}$ for a 10-year-old child. Schwartz's formula can be applied for estimation of GFR.
Schwartz's formula (applicable for children 2 years or older and younger than 12 years)

Estimated GFR $\left(\mathrm{mL} / \mathrm{min} / 1.73 \mathrm{~m}^{2}\right)=$ height $(\mathrm{cm}) \times$
$0.55 /($ serum $\mathrm{Cr}+0.2)$

Note: the serum creatinine value is added with 0.2 to convert a value measured by the enzyme method to that by the Jaffe method.

- Normal blood pressure values for children differ from those for adults: $95-110 / 60-75 \mathrm{mmHg}$ for 3-6 years of age and 100-120/60-75 mmHg for 6-12 years.

- Unlike in adults, it is rare for a malignant tumor to be found in a group with mild hematuria alone.

- Not infrequently, protein is excreted in the urine in cases of orthostatic proteinuria or postural proteinuria. Therefore, urine should be collected not only at a medical office, but also at home as the morning first urine.

\section{Diagnosis and treatment of primary disease}

- When urinary abnormality or kidney dysfunction is found, a patient should be examined for hypoplastic/dysplastic kidney and hydronephrosis by ultrasonography.

- Renal biopsy is considered in cases where there is: 0.5$1.0 \mathrm{~g}$ protein $/ \mathrm{m}^{2} /$ day (per day/per unit body surface area), whih is comparable to $>2+$ in the morning urine for 3-6 months and $1.0 \mathrm{~g}$ or over protein $/ \mathrm{m}^{2} /$ day for 3 months. It is recommended that a patient be referred without delay to a pediatric nephrologist when both proteinuria and hematuria are found or when edema as well as hypertension is present.

- A patient with isolated hematuria is managed for diagnosis according to Guidelines for the Diagnosis of 
Fig. 11-1 A diagnostic flowchart of hematuria in children. The data are quoted, with modification, from: The guidelines for diagnosis of hematuria edited by the Japanese Urological Association, the Japanese Society of Nephrology and the Japanese Society of Pediatric Nephrology

Fig. 11-2 A management of $\mathrm{CKD}$ in pediatric patients
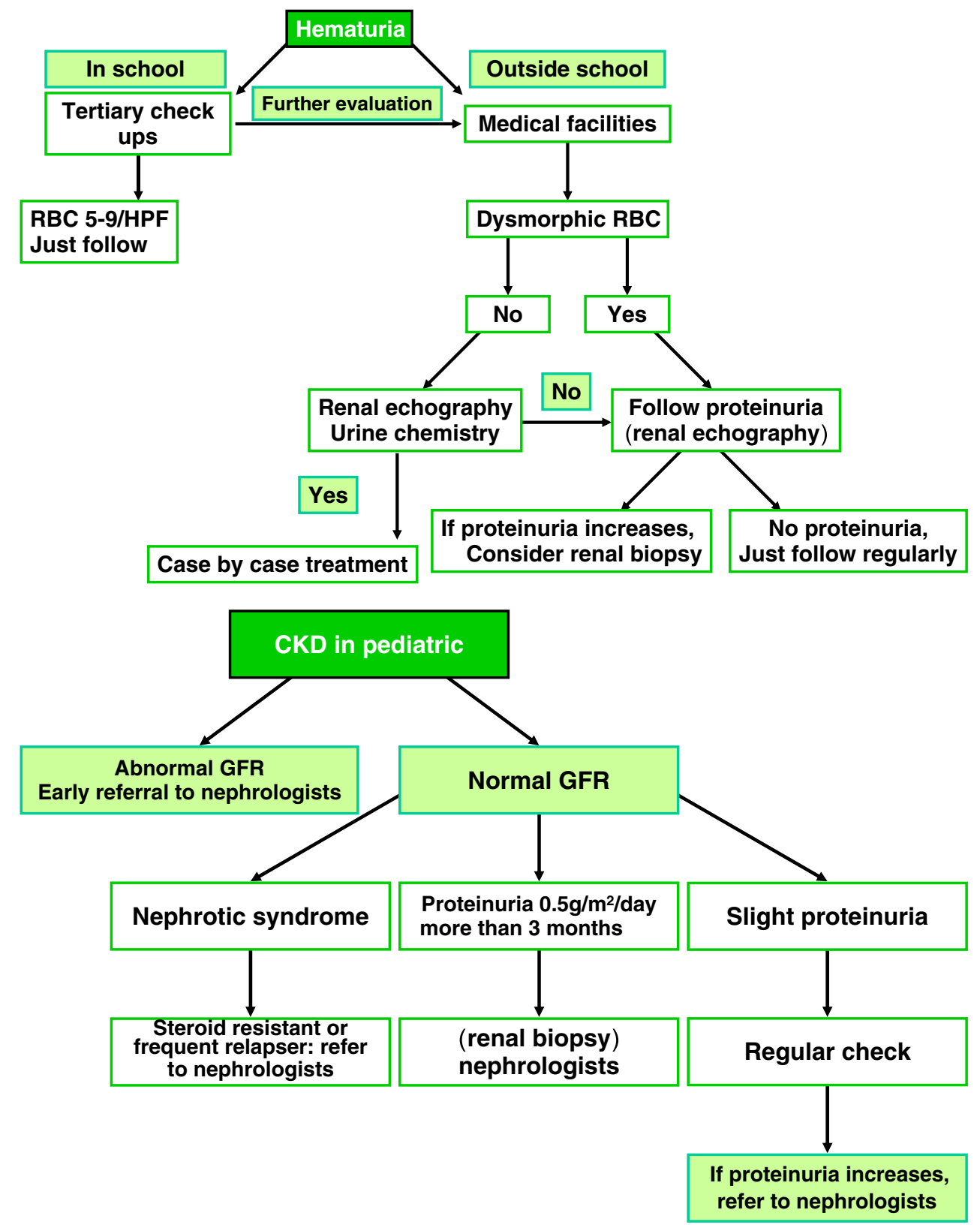

Table 11-1 Kidney disease in children

\begin{tabular}{|c|c|c|c|}
\hline & Primary & Secondary & Hereditary/congenital \\
\hline Glomerular disease & $\begin{array}{l}\text { Minimal change nephrotic syndrome } \\
\text { IgA nephropathy } \\
\text { Focal segmental glomerulosclerosis } \\
\text { Acute glomerulonephritis } \\
\text { Membranoproliferative } \\
\text { glomerulonephritis }\end{array}$ & $\begin{array}{l}\text { Purpura nephritis } \\
\text { Lupus nephritis } \\
\text { Hepatitis B virus-associated } \\
\text { nephropathy }\end{array}$ & $\begin{array}{l}\text { Benign familial hematuria } \\
\text { Alport syndrome, other hereditary nephritis } \\
\text { Congenital nephrotic syndrome }\end{array}$ \\
\hline $\begin{array}{l}\text { Tubulo-interstitial and } \\
\text { urinary tract disease }\end{array}$ & & Fanconi syndrome (include primary) & $\begin{array}{l}\text { Congenital hydronephrosis } \\
\text { Vesico ureteral reflux } \\
\text { Hypoplasia, dysplasia } \\
\text { Polycystic kidney disease } \\
\text { Dent disease } \\
\text { Juvenile nephronophtisis }\end{array}$ \\
\hline
\end{tabular}


Hematuria (the Japanese Urological Association, the Japanese Society of Nephrology, and the Japanese Society of Pediatric Nephrology) (Fig. 11-1).

- After making a diagnosis of CKD, follow-up is carried out according to the protocol illustrated in Fig. 11-2 until a proper time of referral to a nephrologist. It should be remembered that treatment as well as follow-up of pediatric CKD is different from that for adults. Kidney diseases seen in children are listed in Table 11-1. 